\title{
Use of the Bovine Prolactin Gene (bPRL) for Estimating Genetic Variation and Milk Production in Aboriginal Russian Breeds of Bos taurus L.
}

\author{
I.V. Lazebnaya, O.E. Lazebny, S.R. Khatami and G.E. Sulimova \\ Additional information is available at the end of the chapter
}

http://dx.doi.org/10.5772/54756

\section{Introduction}

Prolactin is a protein hormone mainly, but not exclusively produced by lactotroph cells of the anterior pituitary. Its role in lactogenesis and galactopoiesis (maintenance of milk secretion) is well demonstrated [1, 2]. Therefore, the gene encoding it $(P R L)$ is considered to be one of the key links in the gene network constituting the hereditary component of milk productivity. Test systems for cattle breeding have been developed based on the associations of the $P R L$ gene polymorphism with milk yield and quality.

Inbreeding, which decreases the genetic variation and viability of animals, is a well-known negative consequence of artificial selection. Its impact is further aggravated by the recent trend towards globalization of some cattle breeds [3]. Therefore, conservation of aboriginal breeds adapted to local conditions (which are not infrequently extreme) is necessary in countries with wide zonal climatic variations.

This is especially important when a breed in question has pronounced adaptive characteristics and its population is small. Yakut cattle represent one of such breeds (Figure 1a); it is unique among Russian breeds in terms of ecological plasticity. These cattle live in the northernmost part of the Bos taurus species range, a hardly accessible region of the subarctic zone of the Republic of Sakha (Yakutia), Russia, surrounded with mountain ridges. The morphological and physiological characteristics of Yakut cattle and their biochemical and behavioral adaptations allow free grazing almost round the year despite a severe continental climate, with the mean air temperatures usually varying from $-43^{\circ} \mathrm{C}$ in winter to $+25^{\circ} \mathrm{C}$ in summer (the lowest and highest temperatures on record are $-65^{\circ} \mathrm{C}$ and $+38^{\circ} \mathrm{C}$, 
respectively). These animals can live on rough foods. Their body, including the udder, is covered with long, thick hair protecting them from cold and gnats. The color of aboriginal Yakut cattle varies from black and red to a leopard pattern with white spots on the head and lower trunk. This breed is exceptionally resistant to tuberculosis, leukemia, and brucellosis. Yakut cattle are small, with the shoulder height shorter than $1 \mathrm{~m}$ and the live weights of bulls and cows of 500-550 and 350-400 kg, respectively. The milk yield is low (2100-2350 kg in the breeding stock), but the fat content of milk is as high as 7.3\% [4]. Yakut cattle have long been providing local residents (mostly Yakuts) with beef and dairy products. Cattle leather is widely used in Yakut ethnic handicrafts; Yakuts traditionally make comfortable, durable, beautiful leather clothes. Excavations in the Olekminsk district of Yakutia have revealed remnants of nomad camps containing fossil bones of domestic cattle, which suggests an ancient origin of this breed [5].

Bestuzhev and Kostroma cattle are dual-purpose breeds. Bestuzhev cattle selected for both beef and milk production were bred from local cattle in Samara province, Russia, in the late 18th century (Figure 1b). English Shorthorn cattle were used for its improvement, the offspring being crossed with the Holland, Shorthorn, Simmental, and some other breeds. The breed was completely formed by the mid-19th century. Bestuzhev cattle are well adapted to the continental climate of the Volga basin. The animals are red; the color intensity varies from light-red to dark-red or cherry-red. Some animals have white spots, mostly on the lower trunk, udder, and head. The mean milk yield of Bestuzhev cattle is $5502-8250 \mathrm{~kg}$; the mean fat content of milk is $3.82-4.0 \%$ (the maximum content is $5.5 \%$ ) [4]. Bestuzhev cattle are especially valuable because they are almost free of hereditary diseases and abnormalities and are resistant to tuberculosis and leukemia.

Kostroma cattle are classified with the group of brown cattle (Figure 1c). The breed was registered in 1944. These cattle are characterized by a high growing capacity, strong constitution, and steady inheritance of commercially valuable traits, including a good milk quality. The Kostroma breed is regarded as one of the most productive dual-purpose breeds. The live weights of Kostroma bulls and cows are 800-900 and 550-650 kg, respectively; the fat and protein contents of milk are as high as 3.9 and $3.6 \%$, respectively. The milk yield varies from $6000-8000$ to $10,500 \mathrm{~kg}$ [4]. The Kostroma breed is characterized by a high total frequency of the $B o L A-D R B 3$ gene alleles determining the leukemia resistance (on average, $35.9 \%)[6]$.

Yaroslavl cattle, formed as a native cattle breed in the 16th century, have the highest milk yield and the best milk composition among all native Russian breeds (Figure 1d). Their milk contains, on average, $4.37 \%$ of fat (maximum content, $5.0 \%$ ) and $3.4-3.6 \%$ of protein; the dry matter content is $13.6 \%$ (compared to $12.3-12.5 \%$ in other breeds) [4]. Yaroslavl cattle are usually black, except the white head with a black mask around the eyes and the white lower trunk. Yaroslavl cattle were first mentioned in the literature in the mid-19th century. Bestuzhev cattle were named after the original breeder; Yaroslavl, Yakut, and Kostroma cattle, after the region of origin.

The balance between the increase in the milk yield and quality of cattle breeds and preservation of diversity both within and between breeds of B. taurus is a complicated 
problem. Therefore, analysis of the variation of the gene markers that are affected by artificial selection because of their associations with milk yield and composition would be useful for breed monitoring.

The bovine prolactin gene ( $b P R L)$ is traditionally regarded as a good candidate gene for marker-assisted selection (MAS) [7] for milk production parameters, because it has been located to chromosome 23 at $43 \mathrm{cM}$, close to the quantitative trait loci (QTLs) (36, 41, and 42 cM) [8-11]. In addition, it is known that the binding of the $b P R L$ gene product with its receptor (PRLR) initiates a signaling cascade that activates the transcription of a number of genes, including the genes of milk proteins (caseins and lactalbumin).

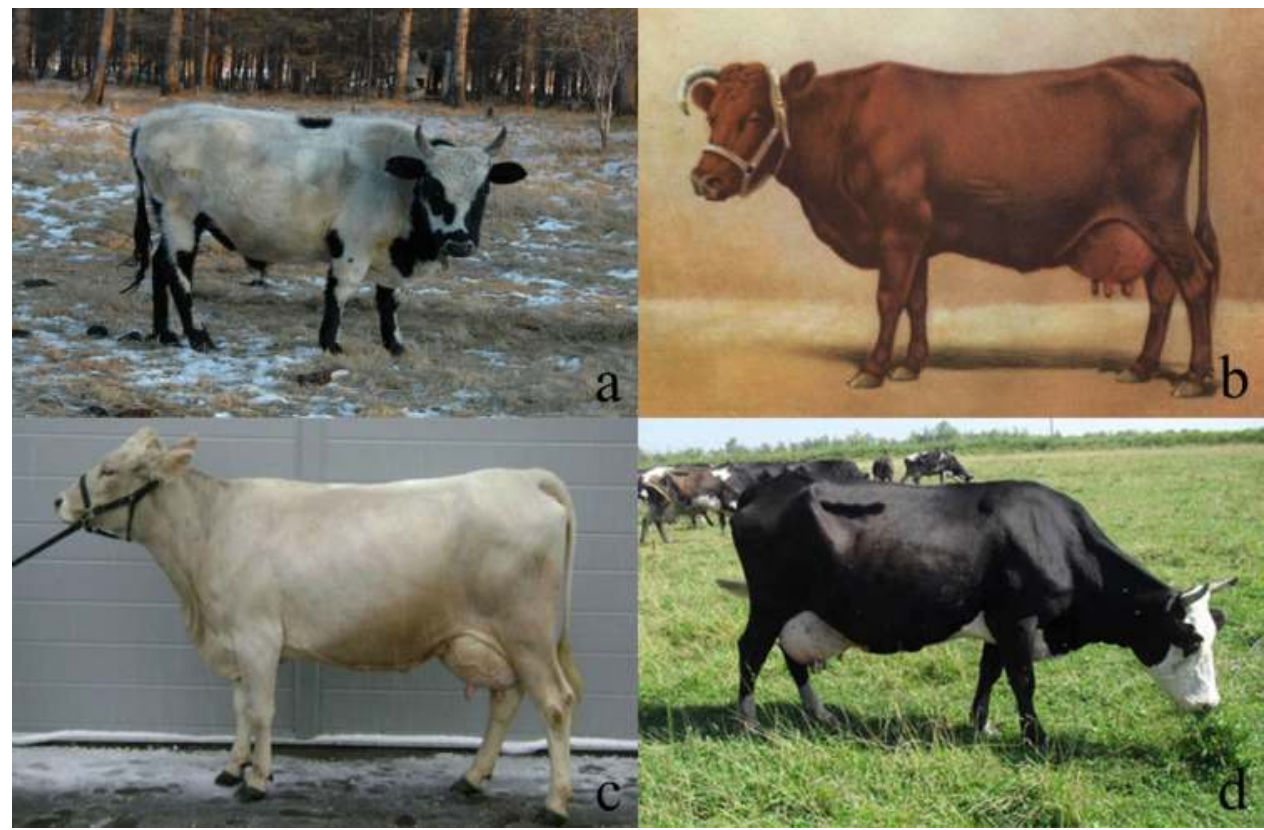

Figure 1. (a) Yakut, (b) Bestuzhev, (c) Kostroma, and (d) Yaroslavl cattle breeds [12, 13, 14, 15].

Note that this regulatory cascade involves growth hormone (Figure 2), because it is recognized not only by its own receptor (GHR), but also by PRLR [16]. The prolactin and growth hormone genes are very similar to each other, because they have resulted from duplication of a common ancestral gene. They have the same general structure (five exons and four introns) [17] and a common positive transcription factor (PITI) [18].

The specifics of the $b P R L$ and $b G H$ genes suggest their combined effect on milk production; however, this has been paid little attention until now. Most studies on the polymorphism of milk production genes deal with isolated effects of individual genes. Many data on the polymorphisms of both $b P R L$ and $b G H$ genes and their relationship with the milk yield and composition have been accumulated. For example, a synonymous A-G transition has been found in the codon of amino acid residue 103 of bPRL in the third exon of its gene; this 
mutation results in an $R s a \mathrm{I}$ polymorphic site [19]. The $A A$ and $A B$ genotypes have been shown to be associated with the milk yield and protein content in Polish Black \& White, Holstein Friesian, and Brown Swiss cattle [19-21]. Other associations have been found in Russian Red Pied cattle [22]. The C-G transversion in the third exon of the $b G H$ gene (nucleotide position 2141) is known to be related to milk production traits. This SNP entails the disappearance of an $A l u \mathrm{I}$ restriction site and the substitution of valine for leucine (Leu $\rightarrow$ Val) at position 127 of the bGH amino acid sequence. There is evidence for a stronger dependence of the milk yield on the $L L$ genotype than the $L V$ genotype in Black Pied and Holstein Friesian cattle [23, 24]. However, Mitra et al. [25] and Dybus et al. [20] note a positive dependence of the milk yield and both fat and protein contents on the $V$ allele in Holstein and Polish Black \& White cattle. Study of the combined effect of the $b P R L$ and $b G H$ genes might explain some contradictions about the associations of individual markers of these genes. Although associations of the $b P R L(R s a \mathrm{I})$ and $b G H(A l u \mathrm{I})$ polymorphisms with milk yield and quality have been extensively studied, the combined effect of SNPs of these genes has been hardly considered at all.

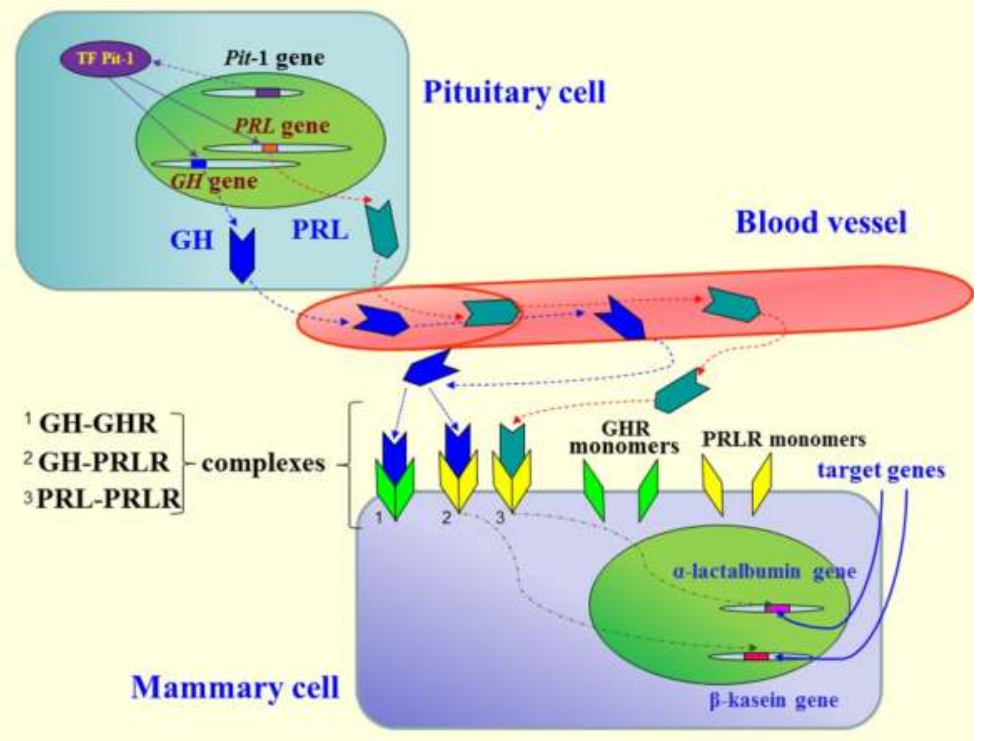

Top: an anterior pituitary cell. Chromosomes carrying the transcription factor (Pit-1), growth hormone (GH), and prolactin $(P R L)$ genes are shown in the nucleus (a green oval). The product of Pit-1 (TF Pit-1) activates the transcription of the prolactin and growth hormone genes. The corresponding hormones (GH and PRL, shown in dark blue and light blue, respectively) enter the bloodstream and reach mammary cells, where they are recognized by transmembrane receptors (GHR and PRLR, respectively). This initiates regulatory cascades activating the transcription of the milk protein ( $\beta$-casein and $\alpha$-lactalbumin) genes. The prolactin and growth hormone receptors are shown in yellow and green, respectively. The growth hormone competes with prolactin for the prolactin receptor.

Figure 2. Schematic representation of the regulatory cascade involving the prolactin gene.

The goal of this study was twofold. First, we compared the Kostroma, Bestuzhev, Yakut, and Yaroslavl breeds both with one another and with some other Russian and foreign 
breeds (literature data) with respect to genetic variation as estimated from the RsaI polymorphism of the prolactin gene. Second, we estimated the effect of the RsaI polymorphism of the $b P R L$ gene, as well as the effect of its combination with the AluI polymorphism of the $b G H$ gene, on milk production in Yaroslavl cattle.

\section{Materials and methods}

We used PCR-RFLP analysis to study the RsaI polymorphism of the $b P R L$ gene in Yakut cattle $(n=41)$ in the Republic of Sakha (Yakutia), Bestuzhev cattle $(n=57)$ in Samara region, Kostroma cattle $(n=124)$ in Kostroma region, and Yaroslavl cattle $(n=113)$ in Yaroslavl region of Russia. The possible effects of the $b P R L(R s a \mathrm{I})$ polymorphism and its combination with the $b G H(A l u \mathrm{I})$ polymorphism on milk production in Yaroslavl cattle were estimated.

DNA was isolated from 200- $\mu$ l samples of whole blood using a Diatom ${ }^{\mathrm{TM}}$ DNA Prep kit (IsoGeneLab., Russia). Fragments of $b P R L$ (156 bp) and $b G H$ (223 bp) [25] were amplified in a Tertsik thermal cycler by the standard methods using a GenePak ${ }^{\mathrm{TM} P C R}$ Core kit (IsoGene Lab., Russia). The DNA digestion with the RsaI and AluI restriction endonucleases was performed as recommended by the manufacturer (MBI Fermentas, Lithuania). The oligonucleotides FPRL (5'-CGAGTCCTTATGAGCTTGATTCTT-3') and RPRL (5'GCCTTCCAGAAGTCGTTTGTTTTC-3') served as primers for the $b P R L$ gene fragments; $F_{G H}$ (5'-GCTGCTCCTGAGGGCCCTTCG-3') and R R $_{G H}$ (5'-GCGGCGGCACTTCATGACCCT-3'), for the $b G H$ gene fragments. The following amplification profiles were used: for the $b P R L$ gene fragments, one cycle of $94^{\circ} \mathrm{C}$ for $4 \mathrm{~min}$; 35 cycles of $94^{\circ} \mathrm{C}$ for $30 \mathrm{~s}, 58^{\circ} \mathrm{C}$ for $30 \mathrm{~s}$, and $72^{\circ} \mathrm{C}$ for $30 \mathrm{~s}$; and one cycle of $72^{\circ} \mathrm{C}$ for $10 \mathrm{~min}$; for the $b G H$ gene fragments, one cycle of $94^{\circ} \mathrm{C}$ for $4 \mathrm{~min}$; 35 cycles of $94^{\circ} \mathrm{C}$ for $45 \mathrm{~s}, 67^{\circ} \mathrm{C}$ for $45 \mathrm{~s}$, and $72^{\circ} \mathrm{C}$ for $45 \mathrm{~s}$; and one cycle of $72^{\circ} \mathrm{C}$ for $10 \mathrm{~min}$. The amplification products were detected by means of $2 \%$ agarose gel electrophoresis $(0.5 \mu \mathrm{g} / \mathrm{ml}$ ethidium bromide in $1 \mathrm{X}$ TBE buffer). The restriction products were visualized in $2 \%$ agarose gel (the $b G H$ gene) or $6 \%$ polyacrylamide gel (the $b P R L$ gene) $(0.5 \mu \mathrm{g} / \mathrm{ml}$ ethidium bromide in $1 \mathrm{X}$ TBE buffer). The results of electrophoresis were recorded by means of a UVT-1 transilluminator (312 nm) and a ViTran-1 photodocumentation system (Biokom, Russia). The alleles were identified as follows: RsaI(-) and RsaI(+) corresponded to the $A$ and $B$ alleles of the $b P R L$ gene, respectively; $A l u \mathrm{I}(-)$ and $A l u \mathrm{I}(+)$, to the $V$ and $L$ alleles of the $b G H$ gene, respectively.

The PopGene [26] and STATISTICA 8.0 [25] software packages were used for statistical treatment of the results. Pairwise comparisons of the allele and heterozygote frequencies

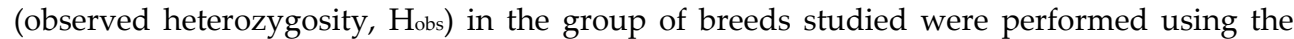
Fisher exact test. For similar comparisons using published data on other Russian and foreign breeds, we additionally calculated the expected heterozygosity ( $\left.\mathrm{H}_{\exp }\right)$ where its values were not presented. The $\mathrm{G}^{2}$ test was used for pairwise comparisons of the breeds with respect to the genotype frequencies and Hexp. The fit of the observed frequencies of heterozygous genotypes to those expected from the Hardy-Weinberg equilibrium was tested using the PopGene software. The dependence of the milk yield (in kilograms) and fat and protein contents (in percent) on the $b P R L$ and $b G H$ genotypes in Yaroslavl cattle was estimated by one-way and two-way ANOVA with the use of the STATISTICA 8.0 software. 


\section{Results and discussion}

\subsection{Genetic structure}

The genotype and allele frequencies of the $b P R L$ gene studied in four Russian cattle breeds are shown in Table 1.

\begin{tabular}{|l|l|l|l|l|l|l|}
\hline Breed & \multicolumn{4}{|l|}{$b P R L(R s a I)$ genotypes } & \multicolumn{2}{l|}{ RsaI alleles of the $b P R L$ gene } \\
\hline \multirow{2}{*}{$\begin{array}{l}\text { Yakut } \\
(n=41)\end{array}$} & $(n)$ & $A A(23)$ & $A B(14)$ & $B B(4)$ & $A(60)$ & $B(22)$ \\
\cline { 2 - 7 } & $p \pm$ s.e. & $0.561 \pm 0.078$ & $0.341 \pm 0.074$ & $0.098 \pm 0.046$ & $0.732 \pm 0.098$ & $0.268 \pm 0.098$ \\
\hline \multirow{2}{*}{$\begin{array}{l}\text { Yaroslavl } \\
(n=113)\end{array}$} & & Hexp \pm s.e. & $0.393 \pm 0.120$ & & & \\
\cline { 2 - 7 } & $p \pm$ s.e. & $0.425 \pm 0.047$ & $0.442 \pm 0.047$ & $0.133 \pm 0.032$ & $0.646 \pm 0.064$ & $0.354 \pm 0.064$ \\
\cline { 2 - 7 } & & Hexp \pm s.e. & $0.461 \pm 0.066$ & & & \\
\hline \multirow{2}{*}{$\begin{array}{l}\text { Bestuzhev } \\
(n=57)\end{array}$} & $(n)$ & $A A(27)$ & $A B(24)$ & $B B(6)$ & $A(78)$ & $B(36)$ \\
\cline { 2 - 7 } & $p \pm$ s.e. & $0.474 \pm 0.066$ & $0.421 \pm 0.065$ & $0.105 \pm 0.041$ & $0.684 \pm 0.087$ & $0.316 \pm 0.087$ \\
\hline \multirow{2}{*}{$\begin{array}{l}\text { Kostroma } \\
(n=124)\end{array}$} & $(n)$ & $A A(69)$ & $A B(48)$ & $B B(7)$ & $A(186)$ & $B(62)$ \\
\cline { 2 - 7 } & $p \pm$ s.e. & $0.556 \pm 0.045$ & $0.387 \pm 0.044$ & $0.056 \pm 0.021$ & $0.750 \pm 0.055$ & $0.250 \pm 0.055$ \\
\hline
\end{tabular}

Notes: $p \pm$ s.e. is the genotype (allele) frequency and its standard error; the number of animals with the given genotype is indicated in parentheses; $n$ is the sample size; $\mathrm{H}_{\exp } \pm$ s.e. is the expected heterozygosity and its standard error.

Table 1. The frequencies of the RsaI restriction genotypes and alleles of the $b P R L$ gene in four Russian cattle breeds

The $\mathrm{G}^{2}$ test did not show significant differences between the breeds studied with respect to the genotype or allele frequencies for the $b P R L$ gene. The genotype frequency distributions in the breeds studied fit the Hardy-Weinberg equilibrium. The $A$ allele was prevailing in all breeds studied; its frequency was two to three times higher than the $B$ allele frequency. Thus, these breeds had similar genetic structures in terms of the given SNP despite their different origins and directions of artificial selection.

The distribution of the $R s a \mathrm{I}$ alleles of the $b P R L$ gene is characterized by a higher frequency of the $A$ allele in most breeds studied (Figure 3). In Indian Jersey cattle [28], the frequencies of the two alleles were approximately equal. The $A$ allele frequency was lower in Polish Jersey cattle [29], which deserves special attention. These differences in allele frequencies may have resulted from different histories of selection for milk yield in different breeds. The breeds of $B$. taurus exhibit a considerable genotypic variation with respect to the $b P R L$ gene marker used in this study. This can be seen in the diagram of the genotype frequency distribution (Figure 4). The group of four Russian cattle breeds studied here significantly differed in the genotype frequency distribution from Russian Black \& White [31] and Russian Red Pied [22], but not Lithuanian Black \& White [30]; ( $<0.006$ with the Bonferroni correction). 


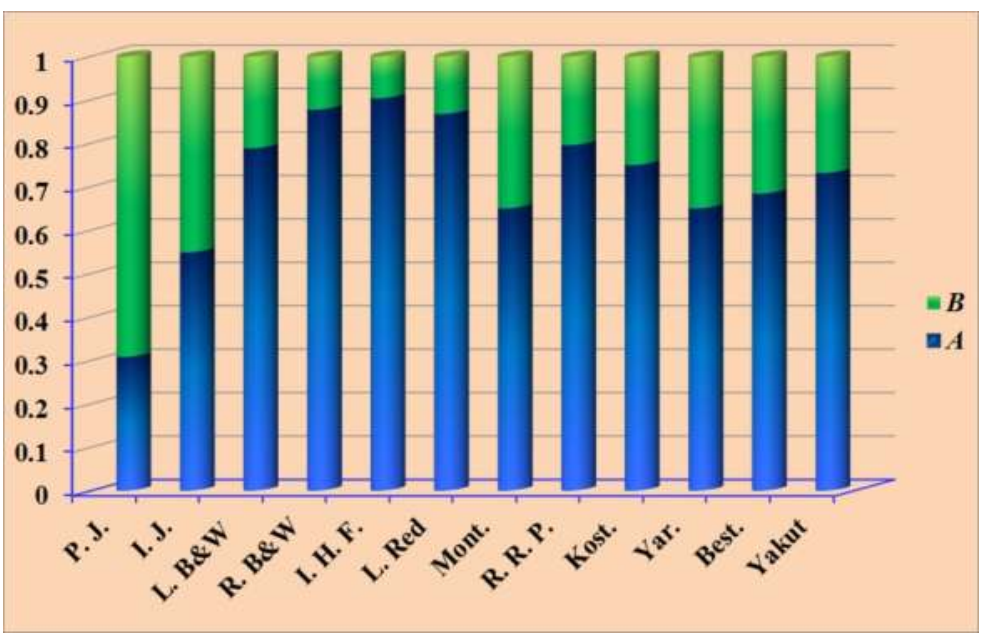

Designations: $A$ and $B$, alleles of the $b P R L$ gene; P, Polish; J, Jersey; I, Indian; L, Lithuanian; B\&W, Black and White; R, Russian; Holstein Friesian; Mont, Montebeliard; R.R.P., Russian Red Pied; Kostr, Kostroma; Yar, Yaroslavl; Best, Bestuzhev.

The diagram is based on published data on Polish Jersey [29], Indian Jersey, Indian Holstein Friesian [28], Lithuanian Black \& White, Lithuanian Red [30], Russian Black \& White [31], Montebeliard [32], and Russian Red Pied [22] cattle.

Figure 3. Distribution of $b P R L(R s a \mathrm{I})$ allele frequencies in the four breeds studied and in other Russian and foreign breeds. The abscissa shows the breeds; the ordinate shows the allele frequencies (in fractions of unity).
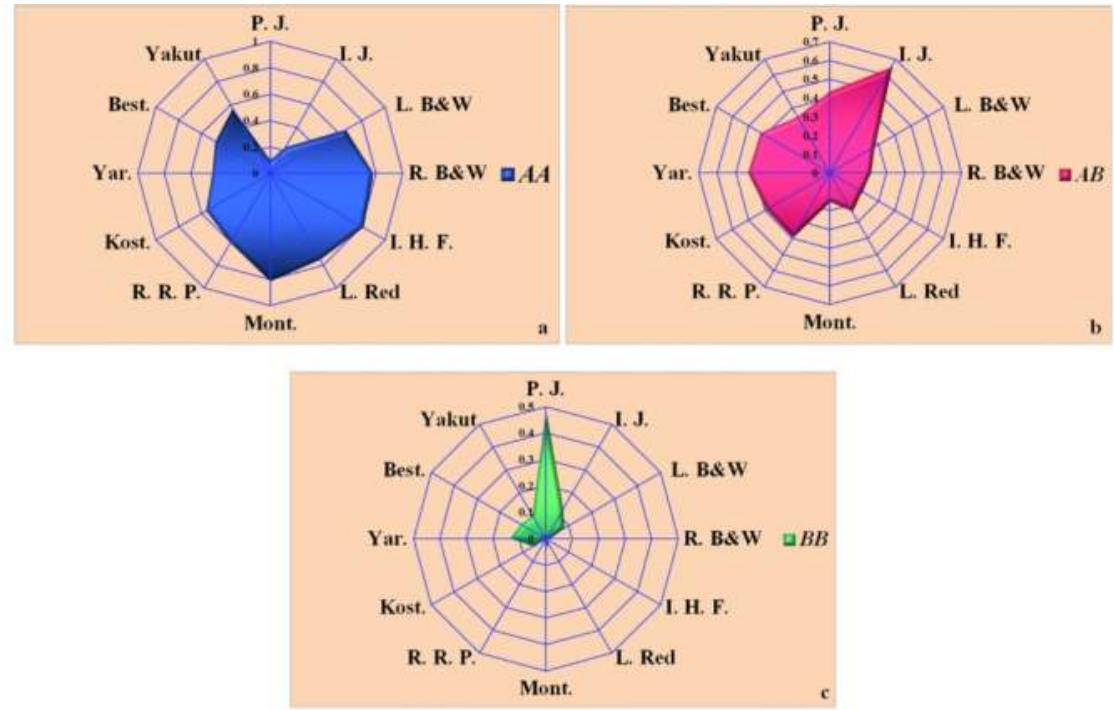

Designations: $A A, A B$, and $B B, b P R L$ genotypes. For designations of the breeds, see Figure 2.

Figure 4. Distribution of $b P R L$ genotype frequencies in the four breeds studied and in other Russian and foreign breeds. The radial axes show the breeds and the corresponding genotype frequencies. 


\subsection{Genetic variation}

The observed ( $\left.\mathrm{H}_{\mathrm{obs}}\right)$ and expected $\left(\mathrm{H}_{\mathrm{exp}}\right)$ heterozygosities (Table 1$)$ for the $b P R L$ gene did not differ significantly from each other in any breed studied; nor did any two breeds differ in these parameters. This was unexpected, considering the substantial differences between these breeds in the Hinfl site of the bPit-1 transcription factor gene (exon 6) and the AluI site of the $b G H$ growth hormone gene (exon 5) (our unpublished data), which are also associated with milk productivity.

In order to compare the genetic diversity in the Russian cattle breeds studied here with those in other Russian and foreign breeds (Figure 5), we calculated the Hexp for all breeds analyzed. The observed and expected heterozygosities for the $b P R L$ gene did not differ significantly in most breeds (Figure 5). The Indian Jersey breed was an exception $\left(\chi^{2}=13.77\right.$, $v=1, p=0.00021)$; the excess of heterozygotes in these cattle apparently resulted from artificial selection.

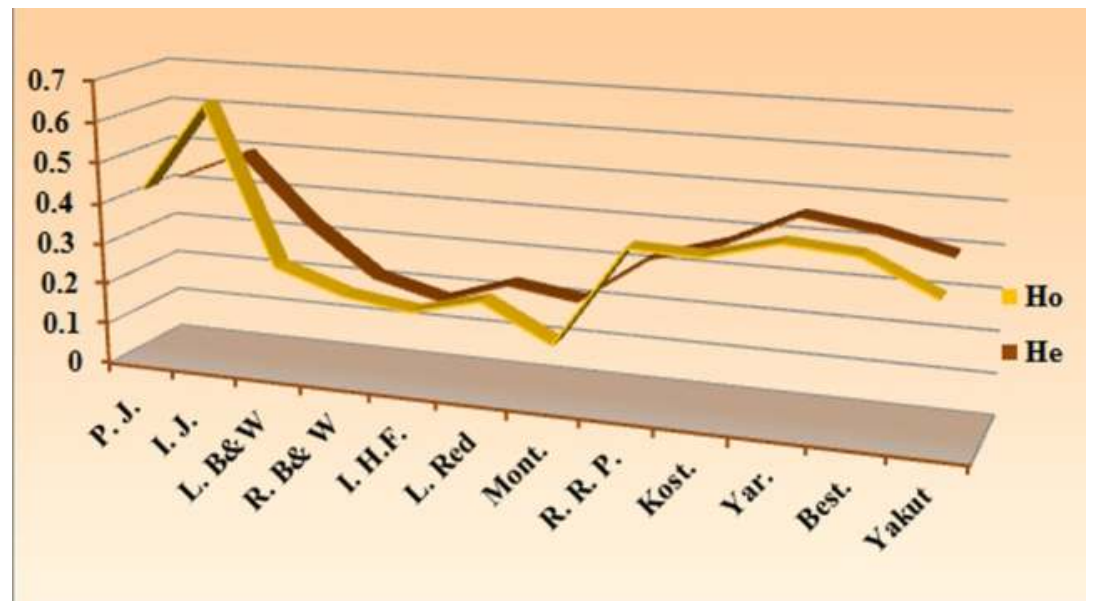

Designations: $\mathrm{H}_{\mathrm{obs}}$ and $\mathrm{H}_{\mathrm{exp}}$, the observed and expected heterozygosities, respectively. For designations of the breeds, see Figure 2. The diagram is based on the expected heterozygosity levels calculated from published data on Montebeliard [32], Russian Red Pied [22], Polish Jersey [29], Lithuanian Black \& White, Lithuanian Red [30], Indian Jersey, and Indian Holstein Friesian [28] cattle.

Figure 5. The observed and expected heterozygosities for the $b P R L$ gene markers in Russian and foreign cattle breeds. The abscissa shows the breeds; the ordinate shows the heterozygosity coefficients (in fractions of unity).

Four Russian breeds studied did not differ from one another in the genetic variation ( $\left.\mathrm{H}_{\exp }\right)$. At the same time, as can be seen in Figure 5, this group had significantly higher Hexp values compared to Russian Red Pied [22] Indian Holstein Friesian [28], and Montebeliard [32], cattle $\left(\mathrm{G}^{2}=36.13, v=4, p=3.0 \cdot 10^{-7} ; \mathrm{G}^{2}=39.19, v=4, p=1.0 \cdot 10^{-7} ; \mathrm{G}^{2}=16.72, v=4, p=0.0022\right.$; and $\mathrm{G}^{2}=19.41, v=4, p=0.0007$, respectively; after the Bonferroni correction).

Thus, the heterozygosity levels in the Kostroma, Bestuzhev, Yakut, and Yaroslavl breeds are significantly higher than in the breeds used for comparison. This indicates a stable state of 
the breeds studied. However, since artificial selection alters genetic variation, regular monitoring of cattle breeds for the given RsaI genetic marker is advisable.

\subsection{Search for associations of SNPs of the prolactin and somatotropin genes with milk production traits in Yaroslavl cattle}

Advances in molecular genetic analysis based on PCR have given rise to novel marker systems for direct genotyping at the DNA level that are independent of the animal's sex and age. This makes the procedures less time-consuming and more accurate.

The RsaI polymorphism of the $b P R L$ gene (Table 1), as well as the AluI polymorphism in exon 5 of the $b G H$ gene, was used to search for associations of these genes with milk production traits, including the milk yield and milk fat and protein contents, in Yaroslavl cattle. We found the following frequency distribution of genotypes: $L L(n=32), 0.283 \pm 0.042$; $L V(n=63), 0.558 \pm 0.047 ; V V(n=18), 0.159 \pm 0.034$. The genotype frequency distribution in these breeds fit the Hardy-Weinberg equilibrium. Table 1 shows the frequency distribution of $b P R L$ genotypes. AAVL $(n=29)$ and $A B V L(n=27)$ are the most frequent combined genotypes of these genes; the $A A L L$ and $A B L L$ genotypes are somewhat rarer $(n=12$ and $n=$ 16 , respectively).

We used ANOVA to estimate the isolated effect of the $b P R L$ gene and the combined effect of the $b P R L$ and $b G H$ genes on milk production traits (the milk yield in kilograms and the percentage fat and protein contents for the first three lactations) in Yaroslavl cattle. Table 3 shows the dependence of these parameters for the third lactation on the $b P R L(R s a \mathrm{I})$ polymorphism as estimated by one-way ANOVA. The $b P R L$ gene was found to affect the fat content of milk $\left(F_{(2 ; 63)}=3.18, p=0.048\right)$ but not the milk yield or protein content.

\begin{tabular}{|c|c|c|c|c|c|c|c|c|c|}
\hline & \multicolumn{9}{|c|}{ Lactation 3} \\
\hline & & \multicolumn{4}{|c|}{ Milk Yield (kg) } & \multicolumn{4}{|c|}{ Fat (\%) } \\
\hline Factor & D. F. & SS & MS & $\mathrm{F}$ & $\mathrm{P}$ & SS & MS & $\mathrm{F}$ & $\mathrm{P}$ \\
\hline$P R L($ Rsa 1$)$ & 2 & 0.03 & 0.015 & 0.5 & 0.629 & 0.002 & 0.001 & 3.19 & 0.0478 \\
\hline \multirow[t]{3}{*}{ Error } & 63 & 2.021 & 0.032 & & & 0.0232 & 0.0004 & & \\
\hline & & \multicolumn{4}{|c|}{ Protein $(\%)$} & & & & \\
\hline & & SS & MS & $\mathrm{F}$ & $\mathrm{P}$ & & & & \\
\hline Rsa1(PRL) & 2 & 0.0005 & 0.0003 & 2.34 & 0.104 & & & & \\
\hline Error & 63 & 0.0073 & 0.0001 & & & & & & \\
\hline
\end{tabular}

Designations: d.f., number of degrees of freedom; SS, sum of squares; MS, mean sum of squares, $F$, Fisher's test; $p$, probability; Error, residual variance.

Table 2. Results of one-way ANOVA showing the dependence of milk production traits for the third lactation on the $P R L(R s a \mathrm{I})$ polymorphism in Yaroslavl cattle

Figures 6a-6c show the dependences of three milk production traits on the $b P R L$ genotypes in Yaroslavl cattle. As can be seen in Figure 6a, cows with the $A A$ genotype exhibited a significantly higher fat content of milk compared to $B B$ cows $(p=0.037)$. 

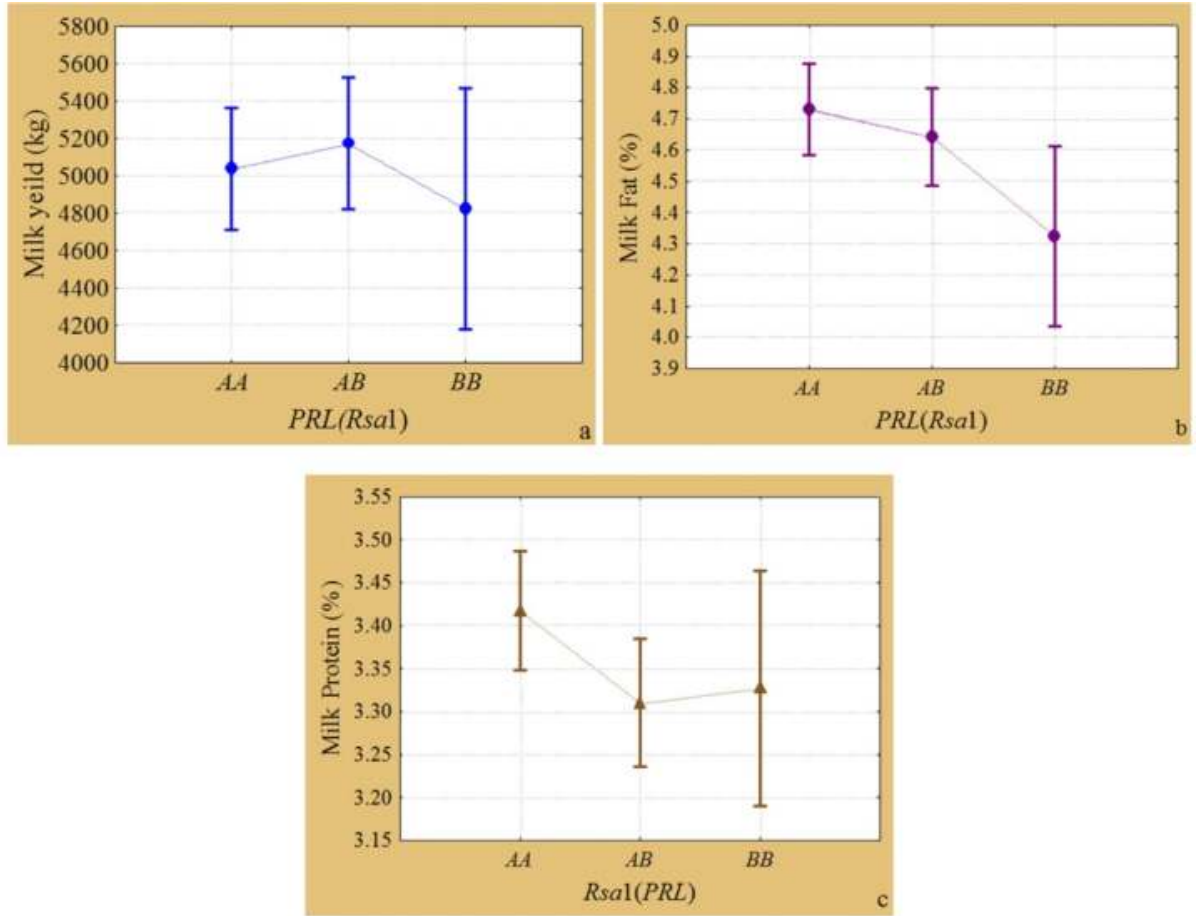

Figure 6. Dependence of (a) the milk yield (in kilograms), (b) the fat content, and (c) the protein content of milk of the third lactation on the $b P R L$ genotypes in Yaroslavl cattle. The abscissas show the $b P R L$ genotypes; the ordinates show the mean values of the traits; vertical bars are 0.95 confidence intervals.

Considering that quantitative traits, including milk production traits, are each determined by a number of genes, we also estimated the possible combined effect of two factors, the $b P R L$ and $b G H$ genes, on the milk production traits using two-way ANOVA. The analysis did not reveal a significant isolated effect of any one-locus genotype for any lactation. Still it showed that the $b P R L$ genotype tended to affect the third-lactation milk fat content $(p=$ 0.064), which was in contrast to the results of one-way ANOVA showing its significant effect (Table 2). Like one-way ANOVA, the two-way analysis demonstrated that $A A$ cows were characterized by a higher fat content of milk than $B B$ cows. However, the main result concerning the relationship between the $b P R L$ and $b G H$ gene polymorphisms and milk production was that we found combined effects of these two genes on the fat and protein contents of first-lactation milk in Yaroslavl cattle $\left(F_{(4 ; 104)}=2.59, p=0.041\right.$ and $F_{(4 ; 104)}=2.93, p=$ 0.024, respectively) (Table 3).

In order to identify the genotypes whose carriers significantly differed in the mean percentage fat and protein contents of milk, we performed post-hoc pairwise comparisons of these traits in cows with different combined genotypes of the $b P R L$ and $b G H$ genes. Table 4 shows the results of this analysis. In terms of the milk fat content, cows with the $A B L L$ 
genotype significantly differed from those with the $A A V L, A A L L, A B V V$, and $B B V L$ genotypes; and cows with the $B B V V$ genotype significantly differed from those with the $A B V V$ and $B B V L$ genotypes. In terms of the milk protein content, $A A L L$ cows significantly differed from $A A V V, A B V L, A B L L$, and $B B L L$ cows; and $B B V V$ cows, from $B B L L$ ones.

\begin{tabular}{|c|c|c|c|c|c|c|c|c|c|}
\hline \multirow[t]{3}{*}{ Effect } & \multicolumn{9}{|c|}{ Lactation 1} \\
\hline & \multirow{2}{*}{$\frac{\text { Trait }}{\text { D.f. }}$} & \multicolumn{4}{|c|}{ Milk Yield } & \multicolumn{4}{|c|}{ Fat $(\%)$} \\
\hline & & SS & MS & $\mathrm{F}$ & $\mathrm{P}$ & SS & MS & $\mathrm{F}$ & $\mathrm{P}$ \\
\hline$P R L(R s a \mathrm{I})$ & 2 & 0.006 & 0.003 & 0.2 & 0.858 & $4.0 \mathrm{E}-05$ & 2.0E-05 & 0.060 & 0.939 \\
\hline$G H(A l u \mathrm{I})$ & 2 & 0.084 & 0.042 & 2.1 & 0.123 & 0.001 & $2.6 \mathrm{E}-04$ & 0.920 & 0.401 \\
\hline $\begin{array}{l}P R L(R s a \mathrm{I}) \\
{ }^{*} G H(A l u \mathrm{I})\end{array}$ & 4 & 0.064 & 0.016 & 0.8 & 0.520 & 0.003 & 0.001 & 2.590 & 0.041 \\
\hline \multirow[t]{3}{*}{ Error } & 104 & 2.049 & 0.020 & & & 0.029 & $2.8 \mathrm{E}-04$ & & \\
\hline & \multicolumn{5}{|c|}{ Lactation 1} & & & & \\
\hline & Trait & \multicolumn{4}{|c|}{ Protein $(\%)$} & & & & \\
\hline Effect & D.f. & SS & MS & $\mathrm{F}$ & $\mathrm{P}$ & & & & \\
\hline$P R L(R s a \mathrm{I})$ & 2 & $2.4 \mathrm{E}-05$ & $1.2 \mathrm{E}-05$ & 0.100 & 0.908 & & & & \\
\hline$G H(A l u \mathrm{I})$ & 2 & 2.3E-04 & $1.1 \mathrm{E}-04$ & 0.890 & 0.412 & & & & \\
\hline $\begin{array}{l}P R L(R s a \mathrm{I}) \\
{ }^{*} G H(A l u \mathrm{I})\end{array}$ & 4 & 0.001 & 3.7E-04 & 2.930 & 0.024 & & & & \\
\hline Error & 104 & 0.013 & 1.3E-04 & & & & & & \\
\hline
\end{tabular}

Designations are the same as in Table 2.

Table 3. Results of two-way ANOVA showing the dependence of the milk production parameters on the $b P R L$ and $b G H$ genes and their interaction in Yaroslavl cattle

Figure 7 graphically shows the combined effects of the $b P R L$ and $b G H$ genes. The milk yield (in kilograms) and the fat and protein contents of milk of the first lactation in Yaroslavl cows are plotted in Figures $7 \mathrm{a}, 7 \mathrm{~b}$, and $7 \mathrm{c}$, respectively, against the $b P R L$ genotypes $(A A, A B$, and $B B)$. The $b G H$ genotypes are indicated by dots of different colors. The points corresponding to the same $b G H$ genotype but different $b P R L$ genotypes are connected by dotted lines. As evident from Figure 7, there was no consistent dependence of the fat or protein content on the dose of any allele of any gene. Let us consider how the mean milk fat content depended on the $b P R L$ genotypes in combination with different $b G H$ genotypes (Figure $7 \mathrm{~b}$ ). The combinations of the $A A$ genotype of the $b P R L$ gene with different $b G H$ genotypes did not differ significantly from one another, and neither did the combinations of the $B B$ genotype of the $b P R L$ gene with different $b G H$ genotypes. In contrast, the mean percentage fat content of milk of $A B$ cows was significantly lower if they had the $L L$ genotype of the $b G H$ gene than if they had the $V V$ genotype. This indicates gene interaction, which should be taken into account because otherwise the effects of individual genes on the formation of these traits 
would be incorrectly estimated. Note that, among the combined genotypes of the $b P R L$ and $b G H$ genes shown in Figure 7, the $A A L L, A A V L, A B V V$, and $B B V L$ genotypes were characterized by a significantly higher milk fat content of milk compared to the $A B L L$ gene (Figure $7 b$ ).

\begin{tabular}{|c|c|c|c|c|c|c|c|c|c|}
\hline \multicolumn{7}{|c|}{ Combined $b P R L$ and $b G H$ genotypes $(b P R L(R s a \mathrm{I})-b G H(A l u \mathrm{I}))$} \\
\hline & $A A V V$ & $A A V L$ & $A A L L$ & $A B V V$ & $A B V L$ & $A B L L$ & $B B V V$ & $B B V L$ & $B B L L$ \\
\hline$A A V V$ & & 0.933 & 0.725 & 0.243 & 0.945 & 0.182 & 0.272 & 0.267 & 0.968 \\
\hline$A A V L$ & 0.102 & & 0.701 & 0.163 & 0.809 & $\mathbf{0 . 0 4 1}$ & 0.175 & 0.186 & 0.984 \\
\hline$A A L L$ & $\mathbf{0 . 0 3 8}$ & 0.378 & & 0.336 & 0.572 & $\mathbf{0 . 0 4 4}$ & 0.139 & 0.369 & 0.806 \\
\hline$A B V V$ & 0.067 & 0.484 & 0.986 & & 0.125 & $\mathbf{0 . 0 0 8}$ & $\mathbf{0 . 0 3 8}$ & 0.955 & 0.339 \\
\hline$A B V L$ & 0.432 & 0.181 & $\mathbf{0 . 0 5 8}$ & 0.125 & & 0.069 & 0.218 & 0.143 & 0.919 \\
\hline$A B L L$ & 0.733 & 0.086 & $\mathbf{0 . 0 2 9}$ & 0.068 & 0.570 & & 0.882 & $\mathbf{0 . 0 0 9}$ & 0.259 \\
\hline$B B V V$ & 0.058 & 0.343 & 0.725 & 0.736 & 0.108 & 0.064 & & $\mathbf{0 . 0 4 2}$ & 0.312 \\
\hline$B B V L$ & 0.559 & 0.368 & 0.153 & 0.208 & 0.960 & 0.727 & 0.159 & & 0.36 \\
\hline$B B L L$ & 0.713 & 0.086 & $\mathbf{0 . 0 3 6}$ & 0.054 & 0.293 & 0.491 & $\mathbf{0 . 0 4 5}$ & 0.387 & \\
\hline
\end{tabular}

Table 4. Results of post-hoc comparisons of the mean first-lactation fat (above the diagonal) and protein (below the diagonal) contents of milk of Yaroslavl cows with different combined $b P R L-b G H$ genotypes

Regarding the dependence of the mean protein content of milk in Yaroslavl cattle on the $b P R L$ genotypes combined with different $b G H$ genotypes (Figure 7c), the combined $A A L L$ genotype differs from $A A V V$, and $B B V V$ differed from $B B L L$. In contrast, no combination of the $A B$ genotype of $b P R L$ with a $b G H$ genotype differed from its combination with any other $b G H$ genotype in this respect. Note that, in the given sample of Yaroslavl cattle, the $A A V V, A B L L$, and $B B L L$ genotypes were preferable over the $A A L L$ genotype in terms of the percentage protein content of milk, as was the $B B L L$ genotype over the $B B V V$ genotype.

Thus, in Yaroslavl cattle, the $A A$ genotype of the $b P R L$ gene was characterized by a significantly higher percentage fat content of milk than the $B B$ genotype, in contrast to Russian Red Pied cattle, where $A B$ cows had a higher milk fat content than $A A$ and $B B$ cows $(p<0.05)$ [22]. Our study has been the first to demonstrate the combined effect of the $b P R L$ and $b G H$ genes (i.e., their combined genotypes) on the milk fat and protein contents. A number of other authors have also studied the relationship of milk production with combined genotypes of SNPs in the same or different genes; however, the possibility of their combined effect has almost never been considered. One exception is the study on the effects of the combined genotypes of the $A l u \mathrm{I}$ and $M s p \mathrm{I}$ polymorphic sites in exon 5 and intron 3, respectively, of the growth hormone gene in Polish Black \& White cattle [20]. However, these authors studied combined $b G H$ genotypes as a single factor; hence, they did not consider the effect of interaction between individual SNPs on the traits studied. In addition, the marker system used by them was hardly suitable for revealing the interaction of these SNPs because they were located in the same gene. 

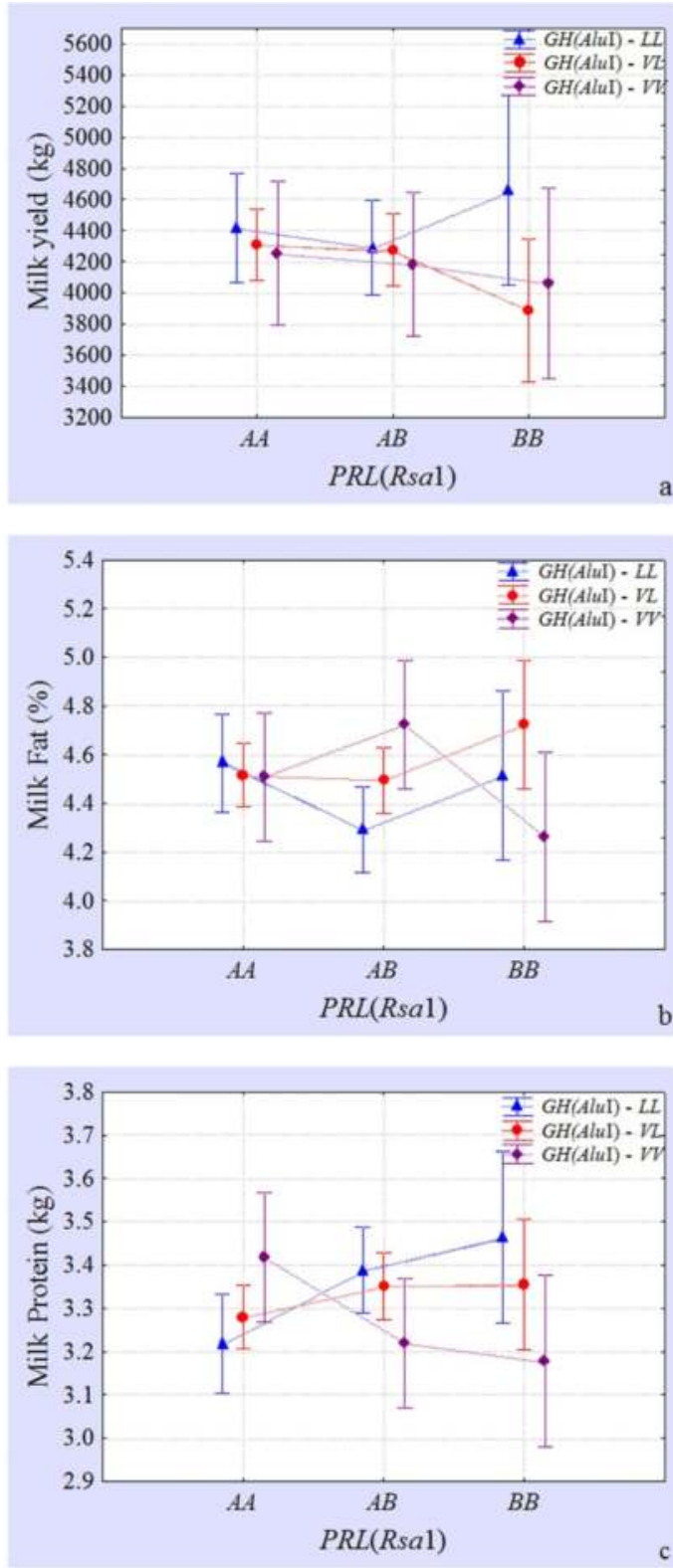

Figure 7. Dependence of (a) the milk yield (in kilograms), (b) the fat content, and (c) the protein content of milk of the first lactation on combined genotypes of the $b P R L$ and $b G H$ genes in Yaroslavl cattle. The abscissas show the $b P R L$ genotypes $(A A, A B$, and $B B)$; the ordinates show the mean values of the traits; vertical bars are 0.95 confidence intervals. Different $b G H$ genotypes are denoted by dots of different colors; the points corresponding to the same $b G H$ genotype but different $b P R L$ genotypes are connected by dotted lines. 


\section{Conclusion}

We have found that four Russian cattle breeds, Yakut, Bestuzhev, Kostroma, and Yaroslavl cattle, are similar in genetic structure. All of them are characterized by a low frequency of the $B B$ genotype of the RsaI polymorphic site in the $b P R L$ gene (from $0.056 \pm 0.021$ to $0.133 \pm$ 0.031 ) and high frequencies of heterozygotes and homozygotes for the $A$ allele. The breeds of $B$. taurus exhibit a considerable genotypic variation with respect to the $b P R L$ gene marker used in this study. The group of these four Russian cattle breeds significantly differs in the genotype frequency distribution from other breeds, such as Russian Black \& White and Russian Red Pied. At the same time, these four breeds do not differ significantly in the observed or expected heterozygosity for the $b P R L$ gene either from each other or from other breeds used for comparison.

We have demonstrated a combined effect of the $b P R L$ and $b G H$ genes on the percentage protein and fat contents of milk. Each trait has been found to be significantly positively associated with some of the combined genotypes. No genotype has been found to positively affect both traits. At the same time, some genotypes are associated positively with one trait and negatively with the other one: $A B V V$ cows are characterized by a high fat content and low protein content of milk, while this is the other way round with $A B L L$ cows. This could be used for selecting cattle for high individual productivity traits. Note that only one combined genotype $(B B V V)$ is unfavorable in terms of both traits. However, being doubly homozygous, it may serve as a reserve for obtaining genotypes that are valuable in terms of either fat $(A B V V$ and $B B V L)$ or protein $(A A V V$ and $B B L L)$ content of milk. Thus, the study of the combined effects of the $b P R L$ and $b G H$ genes and the breeding practice taking these effects into account allow the cattle productive potential to be analyzed in more detail. In addition, involvement of epistatic gene interaction in the formation of selectively valuable quantitative traits has been further confirmed.

We believe that data on the $b P R L(R s a \mathrm{I}) \mathrm{SNP}$ marker and the heterozygosity estimates calculated from its allele frequencies may be used in programs for conservation of aboriginal breeds while maintaining the optimal balance between the goals of artificial selection and preservation of the genetic diversity, which is necessary for sustained reproduction of cattle breeds with all their unique characters. This is especially important because of the rapid decrease in the stocks of cattle breeds and the related threat of partial loss of the genetic resources for stockbreeding on a global scale. [33].

\section{Author details}

I.V. Lazebnaya and G.E. Sulimova

Department of Comparative Genetics of Animals, Vavilov Institute of General Genetics, Russian Academy of Sciences, Moscow, Russian Federation 
O.E. Lazebny

Department of Genetics, Koltsov Institute of Developmental Biology, Russian Academy of Sciences, Moscow, Russian Federation

S.R. Khatami

Department of Genetics, Faculty of Science, Shahid Chamran University of Ahvaz, Ahvaz, Iran

Department of Comparative Genetics of Animals,

Vavilov Institute of General Genetics, Russian Academy of Sciences, Moscow, Russian Federation

\section{Acknowledgement}

This study was supported by the Subprogram of the Presidium of the Russian Academy of Sciences "Gene Pools and Gene Diversity," State Contract no. 14.740.11.0164 in the framework of the Federal Target Program "Science and Education Professionals of Innovative Russia," and the Russian Foundation for Basic Research (grant no. 12-04-92214 Mong_a).

\section{References}

[1] Bernichtein S., Touraine P., Goffin V. REVIEW New concepts in prolactin biology. Journal of Endocrinology 2010;206(1) 1-11.

[2] Horseman N.D., Zhao W., Montecino-Rodriguez E., Tanaka M., Nakashima K., Engle S.J., Smith F., Markoff E., Dorshkind K. Defective mammopoiesis, but normal hematopoiesis, in mice with a targeted disruption of the prolactin gene. EMBO Journal 1997;16(23) 6926-6935.

[3] Rischkowsky B., Pilling D., editors. The State of the World's Animal Genetic Resources for Food and Agriculture Food and Agriculture Organization of the United Nations. FAO. Rome. 2007. ISBN 978-92-5-105762-9

[4] Ernst L.K., Dmitriev N.G., Paronyan I.A., editors. Geneticheskie resursy selskokhozyaistvennykh zhivotnykh $\mathrm{v}$ Rossii i sopredel'nykh stranakh (Genetic Resources of Farm Animals in Russia and Neighboring Countries). St. Petersburg, Russia: VNIIGRZh; 1994.

[5] Korotov G.P. Krupnyi Rogatyi Skot Yakutskoi FSSZ i Metody Ego Uluchsheniya (Yakut Cattle and Breeding Methods of Its Improvement). Yakutsk, USSR: Yakutknigoizdat; 1983.

[6] Sulimova G.E., Lazebnaja I.V., Perchun A.V., Voronkova V.N., Ruzina M.N., Badin G.A. Uniqueness of Kostroma breed of cattle from a position of molecular genetics. Advances in science and technology of Agro-Industrial Complex 2011;9 52-54.

[7] Weller J.I. Quantitative Trait Loci Analysis in Animals. London: CABI Publishing; 2001. 
[8] Bennewitz J., Reinsch N., Guiard V., Fritz S., Thomsen H., Looft C., Kühn C., Schwerin M., Weimann C., Erhardt G., Reinhardt F., Reents R., Boichard D., Kalm E. Multiple quantitative trait loci mapping with cofactors and application of alternative variants of the false discovery rate in an enlarged granddaughter design. Genetics 2004;168(2) 10191027.

[9] Ashwell M.S., Rexroad Jr. C.E., Miller R.H., Van Raden P.M., Da Y. Detection of loci affecting milk production and health traits in an elite US Holstein population using microsatellite markers. Animal Genetics 1997;28(3) 216-222.

[10] Zhang Q., Boichard D., Hoeschele I., Ernst C., Eggen A., Murkv B., Pfistergenskow M., Witte L.A., Grignola F.E., Uimari P., Thaller G., Bishop M.D. Mapping quantitative trait loci for milk production and health of dairy cattle in a large outbred pedigree. Genetics 1998;149(4) 1959-1973.

[11] Plante Y., Gibson J.P., Nadesalingam J., Mehrabani-Yeganeh H., Lefebvre S., Vandervoort G., Jansen G.B. Detection of quantitative trait loci affecting milk production traits on 10 chromosomes in Holstein cattle. J. Dairy Sci. 2001;84(6) 15161524.

[12] http:/ / fermer.ru/files/blog/2012/03/137153/yak4.jpg

[13] http://agrolib.ru/rastenievodstvo/item/f00/s00/e0000992/index.shtml

[14] http://agrobk.ru/kostromskaya

[15] http://frunze37.ru/zhivotnovodstvo/

[16] Svensson L.A., Bondensgaard K., Nørskov-Lauritsen L., Christensen L., Becker P., Andersen M.D., Maltesen M.J., Rand K.D., Breinholt J. Crystal Structure of a Prolactin Receptor Antagonist Bound to the Extracellular Domain of the Prolactin Receptor. The Journal of Biological Chemistry 2008;283(27) 1908519094.

[17] Camper S.A., Luck D.N., Yao, Y., Woychik R.P., Goodwin R.G., Lyons R.H., Rottman F.M. Characterization of the bovine prolactin gene. DNA 1984;3(3) 237-249.

[18] Inoue K., Goda H., Mogi Ch., Tomida M., Tsurugano Sh.. Chapter 6. The Role of Glucocorticoids and Retinoic Acid in the Pituitary Endocrine Cell Differentiation. In: Handa R.J., Hayashi Sh., Terasawa E., Kawata M. (eds.) Neuroplasticity, Development, and Steroid Hormone Action. Boca Raton, FL: CRC Press; 2001. p7380.

[19] Chung E.R. Chung E.R., Rhim T.J., Han SK. Associations between PCR-RFLP markers of growth hormone and prolactin genes and production traits in dairy cattle. Korean J. Anim. Sci. 1996;38(X) 321-336.

[20] Dybus A., Grzesiak W., Szatkowska I., Błaszczyk P. Association between the growth hormone combined genotypes and dairy traits in Polish Black-and-White cows. Animal Science Papers and Reports 2004;22(2) 185-194. 
[21] Chrenek P., Huba J., Oravcova M., Hetenyi L., Peskovieova D., Bulla J. Genotypes of $b G H$ and $b P R L$ genes in relationships to milk production. 50th Annual Meeting: Book of Abstracts, 1999, Eaap, Zurich. 1999.

[22] Alipanah M., Kalashnikova L., Rodionov G. Association of prolactin gene variants with milk production traits in Russian Red Pied cattle. Iranian Journal of Biotechnology 2007;5(3) 158-161.

[23] Sabour M.P., Lin C.Y., Smith C. Association of genetic variants of bovine growth hormone with milk production traits in Holstein cattle. Journal of Animal Breeding and Genetics 1997;114(X) 435-442.

[24] Zwierzchowski L., Krzyzewski J., Strzalkowska N., Dymnicki E. Effect of polymorphism of growth hormon (GH), Pit-1, and leptin (LEP) genes,cow's age, lactation stage and somatic cell count on milk yield and composition of Polish Blackand-White cows. Animal Science Papers and Reports 2002;20(4) 213.

[25] Mitra A., Schlee P., Balakrishman C.R., Pirchner F. Polymorphisms at Growth-Hormone and Prolactin Loci in Indian Cattle and Buffalo. Journal of Animal Breeding and Genetics 112, 71-74. 1995

[26] Yeh F.C., Yang R.-C., Boyle T.B.J., Ye Z-H., Mao J.X. PopGene, the User-Friendly Shareware For Population Genetic Analysis. Molecular Biology and Biotechnology Centre, University of Alberta, Canada. 1997.

[27] StatSoft, Inc. STATISTICA (Data Analysis Software System), version 8.0. 2008, www.statsoft.com.

[28] Kumari R., Singh K.M., Soni K.J., Patel R.K., Chauhan J.B., Sambasiva-Rao K.R.S. Genotyping of the Polymorphism Within Exon 3 of Prolactin Gene in Various Dairy Breeds by PCR RFLP (Brief report). Archiv Tierzucht / Archives Animal Breeding 2008;51(3) 298-299.

[29] Dybus A., Grzesiak W., Kamieniecki H., Szatkowska I., Sobek Z., Blaszczyk P., Czerniawska- Piatkowska, E. Zych S., Muszynska M. Association of Genetic Variants of Bovine Prolactin With Milk Production Traits of Black-andWhite and Jersey Cattle. Archiv Tierzucht / Archives Animal Breeding 2005;48(2) 149-156.

[30] Skinkytė R., Zwierzchowski L., Riaubaitė L., Baltrènaitė L., Miceikienė I. Distribution of Allele Frequencies Important to Milk Production Traits in Lithuanian Black and White and Lithuanian Red Cattle. Veterinary Medicine and Zootechnics (Veterinarija ir Zootechnika) 2005;31(53) 93-96.

[31] Goryacheva T.S., Goncharenko G.M. Polymorphism in $\kappa$-Casein and Prolactin Genes and Their Influence on Dairy Productivity of Cows of the Black-and-White Breed. Agricultural biology 2010;4 51-54.

[32] Ghasemi N., Zadehrahmani M., Rahimi G., Hafezian S.H. Associations Between Prolactin Gene Polymorphism and Milk Production in Montebeliard Cows. International Journal of Genetics and Molecular Biology 2009;1(3) 48. 
[33] FAO. 2007. The State of the World's Animal Genetic Resources for Food and Agriculture, edited by Barbara Rischkowsky \& Dafydd Pilling. Rome. 